\title{
Grab the Horns of the Dilemma and Ride the Bull
}

\author{
Rainer Bauböck
}

EU citizenship was conceived almost by stealth through the jurisprudence of the European Court of Justice. When the Maastricht Treaty officially announced its birth, it was quickly dismissed as either 'little more than a cynical exercise in public relations' ${ }^{1}$ or as a 'pie in the sky'. ${ }^{2}$ No longer: Today EU citizenship is hotly contested in public debates in nearly all of the member states. At the heart of this debate is the tension between free movement and social protection. The contributions published in this forum mirror the arguments heard in public arenas at a much higher level of analytical reflection. But what they somehow do not seem to reflect is the heat of the debate. By this I do not mean that scholars should shout insults at each other when they disagree. What I mean is that they should put more emphasis in their analyses on political contestation and participation as core indicators for the salience and strength of democratic citizenship.

I find myself almost entirely in agreement with Maurizio Ferrera's nuanced and well-considered analysis and policy proposals. I agree both with his diagnosis that the burdens created by free movement in Europe threaten to undermine national welfare regimes. There are perceived burdens that erode political support for European integration and real burdens that put strains on local communities and less skilled 'stayers' in the destination as well as the origin countries of mobile EU citizens. I agree also that there is no magic solution for the free movement-social citizenship dilemma, but that building a 'social pillar' of EU citizenship and fortifying it with some 'prosaic duties'(Andrea Sangiovanni) would help to blunt the sharp edges of the dilemma to a certain extent.

Yet I think the dilemma is even sharper than Ferrera and most of our authors acknowledge. The 'permissive consensus' that allowed EU integra-

1 Weiler, J.H.H. (1996), 'European Citizenship and Human Rights', in J. A.

Winter, D. M. Curtin, A.E. Kellerman \& B. De Witte (eds.), Reforming the

Treaty on European Union: The Legal Debate, 57-68. The Hague/Boston:

Kluwer International.

2 Jessurun D’Oliveira, H. U. (1995), 'Union Citizenship: Pie in the Sky?', in

E. Rosas (ed.) A Citizens' Europe: In Search of a New Order, 58-84. London: Sage. 
tion to make sometimes steady and sometimes halting progress without ever retreating is in shatters today. It may be relatively easy to convince the Commission of the incremental improvements proposed by Ferrera, but it seems much more difficult to imagine sufficiently broad policy coalitions involving member state governments that would endorse them. My conclusion will be that bolder proposals for strengthening EU citizenship are worth fighting for, and that in a much more politicised environment they need to be addressed directly to European citizens in attempts to win their support and votes.

I arrive at this conclusion by focusing on two preliminary questions that must be answered before we can discuss how to strengthen EU citizenship. The first one is, as pointed out by Frank Vandenbroucke and Andrea Sangiovanni, that we need to know why we ought to do so. My answer will differ somewhat from theirs. I think that normative reasons to embrace EU citizenship are largely contextual and contingent, but this does not mean that they lack force. The second prior question is what it is that we want to strengthen. This is a question about the nature of EU citizenship, its potential and limits. I argue that the derivative, multilevel and transnational construction of EU citizenship is full of tensions, which creates a need for political rather than purely judicial or technocratic solutions.

\section{A European community of destiny}

For Vandenbroucke, free movement 'means that EU citizens share an opportunity set, which is much larger than the opportunity sets offered by separate national labour markets'. Following Rawls, Vandenbroucke regards equal access to opportunities for all citizens within a polity as a basic principle of justice that is lexically prior to the difference principle, which requires that social inequalities are justified only if they improve the position of the worst-off. This line of reasoning supports giving general priority to free movement where it conflicts with redistributive and regulatory welfare policies, although, according to Vandenbroucke, such conflicts are not inevitable.

Let us assume this liberal view of justice is sound and correctly applied. Why should it then stop at the borders of the EU? Should liberal states not be required to seek to expand their citizens' set of opportunities by concluding reciprocity-based agreements on free movement also with third countries? Switzerland and Norway are already involved in such arrangements with the EU. Why not extend them to Canada, Australia and New Zealand? In fact, reciprocity-based free movement arrangements have existed, prior 
to EU accession, between the UK and Ireland and, independently of the EU, between Australia and New Zealand as well as between several South American states. Moreover, a rapidly increasing number of individuals enjoy today free movement with full access to national labour markets without any coordination between the states involved simply because they possess several nationalities. The point is that, although free movement is the core right of EU citizenship, it is not necessary to form a political union with a common citizenship in order to realise the goal of expanding opportunity sets through international freedom of movement. ${ }^{3}$ In Paul Magnette's terminology introduced by Ferrera, the isopolitical goal of free movement does not require the construction of European Union citizenship, which is to a significant extent sympolitical. So the normative argument for free movement alone cannot explain why EU citizenship needs to be strengthened. What we need first is a clearer idea about what kind of polity the EU is or ought to become. The right balance between free movement and social citizenship depends on our answer to this question.

For Sangiovanni freedom of movement is not a sufficient answer to why citizens should support the goal of a stronger EU citizenship. While free movement expands every citizen's choice set and range of opportunities, it is also politically contested - as the Brexit referendum has clearly demonstrated - and can entail significant costs for local communities and citizens who are - often involuntarily - insufficiently mobile. For Sangiovanni, 'the best response will appeal to a broader conception of social justice for the European Union.' This is indeed an important step towards answering the normative question. Duties of solidarity and social justice in a union explain better why citizens ought to support adding a social pillar or contributory duties to the present content of EU citizenship.

Yet I am not sure this answer is sufficient. As with Vandenbroucke's argument, there is a nagging question raised by global justice theorists: Why should duties of solidarity and social justice stop at the EU borders? First, we live in a world in which states are interconnected and people are interdependent to an extent never seen previously in human history. Conditions for reciprocity-based solidarity are therefore present not only within the EU but on a global scale. Second, disparities in income and wealth are far greater between the EU and Africa than within the Union. Does the EU therefore have a duty to expand the opportunities of African citizens and to include

3 See Bauböck, R. (2014), 'Migration and the Porous Boundaries of Democratic States', in S. Leibfried et al. (eds.), The Oxford Handbook of Transformations of the State, 516-531. Oxford: Oxford University Press. 
them in its conceptions of social justice by offering membership to their states?

Unlike Vandenbroucke's argument from free movement that is by its very nature expansive, the social justice argument could also lead to the opposite conclusion. In a multilevel union of states, citizens can raise the question - and many of them do - why social justice at the level of the Union should take priority over social justice at the national level in cases where the two conflict with each other. If, as John Rawls thought, social justice is a matter of fairness and reciprocity among citizens involved in a comprehensive scheme of cooperation rather than among human beings per se, then it seems prima facie an open question whether the Union ought to add social justice elements to its free movement-based citizenship or should instead let member states strengthen their national schemes of social citizenship and enable them to do so even at the price of some territorial closure.

In my view, the question within which political unit free movement and social justice ought to be realised and reconciled with each other requires an entirely different answer. The European Union has a claim to be supported by its citizens as such a unit - in addition to the state whose nationals they are and in addition to their duties of global justice - because of the historical context in which Europe finds itself today. The EU is not a response to normative requirements of justice beyond the nation-state; it is a response to the conditions for democracy in Europe.

The two most basic conditions for democratic self-government are the prevention of external domination (through war, colonialism or economic domination by external actors) and internal domination (through authoritarian political rule or political domination exercised by powerful economic groups). The European Union was born out of the desire to make war between European states impossible and its expansion to Portugal, Spain, Greece and the former communist states was driven by the desire to prevent forever the return of authoritarian rule in Europe. Threats of internal and external domination of European democracies are, however, still very much present. Today they take the shape of an authoritarian transformation of democracy through right wing populist parties in power and of external economic domination through powerful corporations. The shrinking demographic, economic and military weight of Europe in the world should not be regarded as per se a problem for stabilising democracy, but it provides a strong reason for European states to pool their resources when addressing external threats. 
These are normative reasons why European states have formed the Union and should want to maintain and strengthen it. They are further reinforced by the commitments they have made to each other when deepening integration with each round of amending the European Treaties. And they are supported by rational self-interests to avoid the costs of exit. As Brexit illustrates, these costs are very high - not because Michel Barnier tries to drive them up, but because of the external conditions the EU states are exposed to and because of those internal conditions that they have created together. The latter conditions explain why staying outside is not as costly as leaving. The European Union has in this - prosaic and not at all romantic - sense become a community of destiny. The citizens of such a community have particularistic reasons to enhance its social cohesion and strengthen its democratic legitimacy. And these are reasons that can be communicated in public debates.

I need to register here a disagreement with Richard Bellamy whose commitment to democracy as a mechanism for the public realisation of the equal status of citizens I fully share. Bellamy says that 'to achieve that result, citizens must be able to air their disagreements and deliberate in ways all can see are fair and addressed to their common concerns, all of which assumes a public sphere and shared interests'. Bellamy thinks these conditions are not sufficiently present in the EU to motivate citizens to support trans- and supranational European citizenship. And he invokes the Catalan secession crisis to illustrate the point. 'Where these features are deemed to be lacking, then large numbers of people are likely to be willing to exercise their liberal rights to freedom of speech and association to militate for a political community that can embody them and can only be prevented from doing so through coercion.'

In contrast to this view, I think that the Brexit and Catalan crises serve to demonstrate that there are in fact sufficiently strong public spheres and shared interests at the level of the encompassing EU and Spanish polities and that separatism is the wrong response to the current predicaments. In both Britain and Catalonia, exiteers and unionists represent(ed) about half of the respective populations. Under such conditions, the reasons why one side wins and the other side loses in a referendum have little to do with deeply rooted collective identities or shared interests of all citizens of the polity and a lot to do with the hard-to-predict outcomes of political campaigns. Moreover, the arguments why Britain would be better off outside the EU and Catalonia outside Spain can be demonstrated to be wrong by pretty overwhelming evidence. What drives such separatism is a politics of resentment 
rather than of the common good. In response to perceived and real grievances, the politics of resentment advocates closure or separation at the price of severely damaging the interests of the citizens it claims to represent.

Bellamy is right that the argument appealing to shared interests must be won in the public sphere, but he is wrong to think that these conditions are absent when it comes to European citizenship. European citizens share interests in reducing external and internal threats to democracy; they have committed through their representatives to create a political and not merely economic union; and they are today exposed to public debates in which European issues are at the centre of controversy and discussed simultaneously across Europe.

\section{The DNA of EU citizenship}

Let me now turn to the second preliminary question that is not addressed in Ferrera's essay: What is EU citizenship? Art. 20 (1) TFEU says: 'Every person holding the nationality of a Member State shall be a citizen of the Union. Citizenship of the Union shall be additional to and not replace national citizenship.' This is the DNA of EU citizenship that determines both its potential evolution and its limits. EU citizenship is derived from member state citizenship rather than the other way round. And since it is additional and not substitutive, it adds another layer to national citizenship.

The potential of this construction is that it transforms nationals into multiple citizens whose rights, duties and political memberships are determined not only by their state, but also by a political union of which their state is a member. The construction adds even a third level below the state when it gives non-national EU citizens the right to vote in municipal elections in their host member state. As I have argued elsewhere, EU citizenship encompasses thus at least three levels, each of which has a distinct rule for determining membership. At the national level citizens are determined by circumstances of birth (through descent from citizen parents or birth in the territory) or naturalisation procedures; at the Union level, citizenship is derived from national membership; and at the local level, it includes (or ought to include) all residents in the municipality. ${ }^{4}$

The principles for determining local and national citizens are independent from each other and create thus a potential for conflicts over who counts as a citizen. When 'sanctuary cities' protect undocumented migrants against

4 Bauböck, R. (2014), 'The Three Levels of Citizenship Within the European Union', German Law Journal 15 (5): 751-764. 
deportation, they oppose their own principle of including all residents to the state's power to exclude non-citizens from admission and residence in its territory. By contrast, the derivative nature of EU citizenship is meant to secure that no such conflict can arise. EU citizens are not those who reside in the EU territory, but all those and only those who are nationals of a member state. Yet a potential for conflict emerges through Art. 20(2) that defines those rights that EU citizenship adds to those of national citizenship. Foremost among these is free movement. When the Court of Justice of the European Union (CJEU) defends immediate access of EU job seekers to employment-related social benefits in other member states, it upholds an expansive interpretation of free movement against the attempts of states to protect their distinct social citizenship regimes through territorial closure. Conflicts of this kind are inevitable in any multilevel democracy. They are pervasive also in consolidated federal states, but there federal courts operate as the ultimate arbiters and interpreters of a constitution that regulates the division of competencies between levels of government. In the EU, the Court interprets instead treaty-based citizenship rights agreed to by states with distinct constitutions and welfare regimes. Such constitutional pluralism $^{5}$ makes a union of states fundamentally different from a federal state.

Conflict over citizenship is institutionalised and, as Susanne Schmidt and Richard Bellamy point out, it cannot always be authoritatively resolved by the CJEU. The court is thus often seen as acting politically when it moves forward with daring declarations that 'EU citizenship is destined to become the fundamental status of nationals of the member state. ${ }^{6}$ It followed up when telling member states that they have to take EU law into account when depriving nationals of their citizenship ${ }^{7}$ and have to grant legal residence to EU citizen children of undocumented migrants even if their EU citizenship has not been activated through cross-border movement. ${ }^{8}$ Yet precisely because the CJEU is acutely aware of having to fill political lacunas left open by the legislature, its expansionary moves in matters of citizenship have been regularly followed by retractive 'clarifications'.

\footnotetext{
5 See Weiler, J. H. H. (1999), The Constitution of Europe. Cambridge: Cambridge University Press.

6 Grzelczyk v Centre Public d'Aide Sociale d'Ottignes-Louvain-la-Neuve, (2001) C-184/99.

7 Janko Rottmann v Freistaat of Bayern (2010) C-135/08.

8 Ruiz Zambrano v Belgium (2011) C-34/09.

9 Shirley McCarthy. v Secretary of State for the Home Department (2011)

C-434/09; Murat Dereci and Others. v Bundesministerium für Inneres (2011)

C-256/11; Elisabeta Dano and Florin Dano v Jobcenter Leipzig (2914)

C-333/13.
} 
The institutionalisation of conflict over citizenship creates a strong potential for politicising EU membership rights and statuses also in the legislative branch of the EU (i.e. the Council and Parliament) and the public arenas of member states that has so far been kept at bay. Brexit (and potentially also Scottish and Catalan secession attempts) could unlock the cage. When this happens, those who want to promote European integration should not be caught unprepared but lay out and explain their visions to citizens and voters instead of acting merely as advisors to the Commission.

I tend to think therefore that we need now not merely pragmatic incrementalism but also bold ideas how to develop EU citizenship further in ways that are compatible with its multilevel DNA. This is why I proposed putting on the agenda a direct EU income tax that would create incentives for EU citizens to hold EU legislators politically accountable for their use of tax money and that would introduce a social justice dimension into EU citizenship if such a tax were progressive. ${ }^{10}$ In order to become politically feasible, such a tax must not be added to current national contributions to the budget but diminish them, which would also make the conflict between net contributor and net recipient governments less poisonous. I am perfectly aware that such a proposal requires Treaty change ${ }^{11}$ and is not a vote getter, but if it is integrated into a coherent political platform for strengthening EU citizenship it might stand a chance to find also sufficient electoral support. Which pollster would have predicted before the victories of van der Bellen in Austria and of Emmanuel Macron in France that one could win elections on an unabashedly pro-EU programme in member states whose citizens are among the most Eurosceptic ones?

Yet the constitutional DNA of EU citizenship also sets limits to what kind of animal it can eventually become. Julia Hermann refers to the idea without endorsing it explicitly - of 'a European Republic, in which there are no nation-states anymore, but only regions, cities, and - most importantly citizens.' This is the old notion that Europe must eventually become a federal state - a persistent trope among supporters of European integration that shows a lack of imagination with regard to alternative forms of political community that do not imitate the nation-state template. Such a

10 See Bauböck, R. (2017), Still United in Diversity? The State of the Union Address, Florence, 5 May 2017, available at https://stateoftheunion.eui.eu/ wp-content/uploads/sites/8/2017/05/The-State-of-the-Union-Address-byRainer-Bauböck.pdf.

11 Treaty change would be necessary if an EU tax were to apply to all member states instead of being introduced through enhanced cooperation among a group of them, such as the Euro group. 
'provincialisation' of member states and their citizenship could not come about gradually by transferring ever more competencies to the Union; it would require at some point a radical break. While there is no hard and fast distinction between pooling and transferring internal sovereignty, creating a European republic or federal state would mean that at a specific date member states lose their external sovereignty as independent members of the U.N. and the international state system. It is not impossible to imagine historical conditions under which some states may be ready to abolish themselves in this way. In the history of the U.S., Switzerland and Germany, i.e. quite some time before the consolidation of the international state system, it took civil and international wars to trigger the move from confederation to federation. ${ }^{12}$ If these are the conditions for realising a federal European Republic, then this is hardly a dream worth dreaming.

Martin Seeleib-Kaiser explicitly refers to the U.S. and German examples when spelling out some of the implications of a federalist project: 'For EU citizenship to become truly a fundamental status it is necessary to overcome the differentiation between economically active and non-active EU migrant citizens and finally abolish the residence requirements.' What he fails to mention is that establishing priority for federal citizenship in the post-Civil War $14^{\text {th }}$ amendment to the U.S. Constitution and in unified Germany after 1871 entailed a radical downgrading of the U.S. states and German Länder whose citizenship henceforth was derived from federal citizenship rather than the other way around. If this were really the destiny of EU citizenship, then the member states have every reason to reject it and the power to do so as masters of the Treaties.

In contrast with the other authors in our debate, Bellamy devotes much attention to the nature of EU citizenship. For him, it is inter-national, rather than trans- or supra-national. I find this terminological choice somewhat confusing. It is the citizenship of independent states that is international by nature. Citizenship is not only a domestic legal status that comes with certain rights and duties; it is first of all a mechanism for allocating individuals to states based on reciprocal international recognition of states' right to determine their own citizens and of their personal jurisdiction over these citizens, including to a certain extent also those residing abroad. In contrast to the citizenship of EU member states, citizenship of the Union is not (yet) international in this sense. It is not a legal status that depends on recognition

12 See Schönberger, C. (2005), Unionsbürger: Europas föderales Bürgerrecht in vergleichender Sicht [Europe's federal citizenship in a comparative perspective], Tübingen: Mohr Siebeck. 
by third countries. The right of EU citizens to seek diplomatic and consular protection by other EU states in third countries where the state whose nationals they are is not sufficiently represented creates a potential claim for international recognition but it is far from obvious that third countries are bound to accept this claim. ${ }^{13}$

Bellamy interprets also the concept of 'transnational citizenship' in a way that hardly matches academic debates. For Bellamy, transnational seems to be synonymous to postnational. However, the ample literature on transnationalism in migration studies has used this concept instead to refer to the increasing salience of links between emigrants and their states of origin, i.e. a phenomenon that expands the reach of national identities and citizenship beyond the states' territorial borders instead of creating a new type of postnational political community. Again, it is primarily the citizenship of independent states that has become transnational in this sense, for example through toleration of dual citizenship or granting voting rights to expat citizens. Yet EU citizenship too was from the very beginning constructed as a transnational status, since most of its rights are activated through crossborder activities, while it is the member state of origin that determines who possesses the status and who can enjoy transnational rights within the Union.

My disagreement with Bellamy is, however, probably not merely terminological. Transnational citizenship is also transformative for national citizenship. This is true in the international arena where states increasingly claim extraterritorial jurisdiction, promote nation-building projects beyond their borders and mobilise their diasporas as an economic, cultural and political resource. The potential for inter-state conflict has not yet been tamed by a corresponding evolution of international legal norms. Political theory also has not kept up with developments and remains largely stuck in a dichotomy between domestic and global conceptions of justice or democracy that fails to take into account the increasing salience of transnational political spaces and phenomena that straddle this distinction. Nowhere has the transformative potential of transnational citizenship been greater than in the EU, where freedom of movement has triggered not only a need for top-down regulatory coordination, but also bottom-up adaptation of welfare regimes and social citizenship in the member states.

The transnational nature of EU citizenship greatly enhances the potential for conflict over the determination or specification of citizenship rights and

13 See Moraru, M. B. (2015), Protecting (unrepresented) EU citizens in third countries. The intertwining roles of the EU and its Member States. PhD thesis, European University Institute, Florence. 
duties that is already inherent in a multilevel structure where union citizenship is derived from national citizenship.

\section{Politicising the struggles over EU citizenship}

Thinking about why we ought to strengthen EU citizenship and what the EU citizenship is that should be strengthened pushes me to always the same conclusion. We can no longer rely on European nation-states to provide sufficient protection for democratic citizenship; nor can we rely on a functionalist teleology that pulls European states towards merging into a federal European republic. Both of these perspectives are out of tune with the way the European Union has evolved over time and the way it has constructed its citizenship.

Finally, we can also not rely on the EU as a guarantor of the rule of law and a correspondingly thin liberal citizenship at European level that secures free movement and non-discrimination and leaves it to the member states to sort out their social citizenship problems. Pace Christian Joppke, the EU is no longer just a regulatory regime. It has become a fiercely contested political arena that is not just located in Brussels, Luxembourg and Strasbourg, but is staged today in every national capital and election campaign.

Liberals tend to think of democracy as being only instrumentally valuable in order to maintain the rule of law that secures individual freedom. Liberal egalitarians regard it also as the political regime that offers the best chances to implement distributive regimes that promote social justice. Yet most liberals fail to give serious thought to what is necessary in turn to maintain democracy so that it can deliver these goods.

I have suggested above that the strongest justification for EU integration is that it protects the external and internal conditions for democracy in Europe. Internally, democracy is hard to sustain over time if citizens no longer believe that governments enjoy input legitimacy derived from being authorised through democratic elections and if citizens no longer share a sense of solidarity and special duties among co-citizens. These beliefs are better supported by theories that regard democracy as having not only instrumental but intrinsic value because it realises the ultimate value of popular self-government - albeit in necessarily imperfect ways.

If liberals abandon this idea it will be picked up by nationalist populists. This may not happen in good times where a permissive consensus allows the liberally minded elites to pacify citizens through what Ernest Gellner called 
the Danegeld of economic growth. ${ }^{14}$ But once output legitimacy becomes weaker in times of economic crises and straightjackets, input legitimacy will be the question around which political forces are mobilised.

Europe is in this situation right now. The social deficits of European citizenship have contributed to deepening an emerging cleavage between mobile and static populations that is reflected in political attitudes towards openness and closure. ${ }^{15}$ Ferrera's fine-tuned proposals how to combine a robust defence of free movement with European social protection policies show that the dilemma is not necessarily a tragic one. The very complexity of Europe's constitutional order creates opportunities for experiments and social policy inventions of this kind. Ferrera suggests at the end of his essay that a vision is needed to guide also incremental reforms. I think that maybe even more is needed now. The dilemma is a political one and needs to be addressed in the political arena. By mobilising a politics of resentment among immobile citizens, populists have seized one of its horns and use it as a weapon against the EU. Those who want to strengthen the European Union and its citizenship should not commit the error to seize the other horn and appeal only to the minority of mobile Europeans. The answer to the EU citizenship dilemma must be to grab both of its horns and to risk a rough ride on the back of the bull. This is what a woman in ancient Greek mythology did. Her name was Europa.

Open Access This chapter is licensed under the terms of the Creative Commons Attribution 4.0 International License (http://creativecommons.org/licenses/by/4.0/), which permits use, sharing, adaptation, distribution and reproduction in any medium or format, as long as you give appropriate credit to the original author(s) and the source, provide a link to the Creative Commons license and indicate if changes were made.

The images or other third party material in this chapter are included in the chapter's Creative Commons license, unless indicated otherwise in a credit line to the material. If material is not included in the chapter's Creative Commons license and your intended use is not permitted by statutory regulation or exceeds the permitted use, you will need to obtain permission directly from the copyright holder.

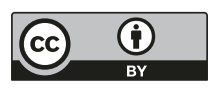

14 Gellner, E. (1983), Nations and Nationalism. Oxford: Blackwell.

15 See Bauböck, R. 'The new cleavage between mobile and immobile Europeans' in Part II of this book. 